\title{
Coping Strategies Adopted by Public Universities in Kenya in Response to Environmental Changes
}

\author{
Francis M. Mathooko ${ }^{1} \&$ Martin Ogutu ${ }^{2}$ \\ ${ }^{1}$ School of Agriculture and Veterinary Sciences, South Eastern Kenya University, Kitui, Kenya \\ ${ }^{2}$ School of Business, University of Nairobi, Nairobi, Kenya \\ Correspondence: Francis M. Mathooko, School of Agriculture and Veterinary Sciences, South Eastern Kenya \\ University, P.O. Box 170 - 90200, Kitui, Kenya. Tel: 254-722-861-239. E-mail: mmathooko@yahoo.co.uk
}

Received: November 28, 2013

Accepted: December 21, $2013 \quad$ Online Published: February 16, 2014

doi:10.5430/jms.v5n1p93

URL: http://dx.doi.org/10.5430/jms.v5n1p93

\begin{abstract}
This study was undertaken to establish strategies adopted by public universities in Kenya in response to changes in the environment. The study design was descriptive and utilized a cross-sectional survey of all the public universities in Kenya through administration of a structured questionnaire to the top management team. Additional primary data were collected through observations and interviews. Secondary data were collected from published works and, universities and government documents in public domain in order to corroborate the data collected from the primary sources. Positive responses were received from 63 respondents out of 91, yielding a $69.4 \%$ response rate. The universities adopted Porter's generic competitive strategy model, of cost leadership, differentiation and focus to counter the challenges experienced, and in particular cost leadership and differentiation. The extent of adoption of differentiation strategy was significantly different $(p<0.05)$ between the old and new universities and not among the three categories of public universities, that is, old, new and university colleges. Grand strategies adopted were diversification in related business, expansion and strategic alliances. The major operational strategies adopted included, management leadership in the formulation of response strategies, distributed leadership, benchmarking, and mounting of evening and weekend programmes. Some operational strategies adopted by some universities were, however, unethical and may compromise quality. The results indicate that the coping strategies adopted by public universities in Kenya in response to changes in the environment are more or less similar to those applied by corporate organizations among them, grand strategies and Porter's generic competitive strategy.
\end{abstract}

Keywords: environmental change, grand strategies, Kenya, operational responses, Porter's generic strategies, public universities, strategy, strategic responses

\section{Introduction}

Higher education world over is undergoing rapid transformation in the face of changing environmental dynamics. In Kenya, this transformation has seen a rapid expansion of public higher education institutions (HEIs) in the recent past making higher education the biggest growth area in Kenya despite the various challenges posed (Mathooko, 2013). The biggest criticism of the proliferation of universities, so far, is that some of the new ones may have the status, but lack personnel and facilities. Like many organizations, the survival, growth and prosperity of these public HEIs depend on how they respond to changes taking place in the environment. In view of this, strategic management plays a key role in positioning them in their quest to achieve sustainable competitive advantage. Therefore, for organizations to remain truly competitive over time as the environment changes, they have to learn to adapt and reorient themselves to the changing environment. For this reason, there has to be a deliberate and coordinated leaning to a gradual systematic realignment between the environment and the organization's strategic orientation that results in improvement in performance, efficiency and effectiveness. In order for an organization to remain successful in its business, there is need to understand the challenges, opportunities and threats that are provided by the external environment, so that the organization can take advantage of the opportunities and avoid threats (Xu, Lahaney, Clarke and Duan, 2003) by applying appropriate response strategies. It is only those firms that have put in place appropriate response strategies that will survive and achieve sustainable competitive advantage. Universities in Kenya today are operating in a highly turbulent and dynamic environment as a result of liberalization of the higher education industry, resulting in an influx of many players. For these institutions to survive in such an environment, their strategies, 
therefore, need to focus on their customers (students, parents and industry) to deal with emerging environmental challenges which in turn pose managerial challenges. A major escalation in environmental turbulence means a change from the familiar world to that of new things, new technologies, new competition, new customers and a new dimension of social control (Ansoff and McDonnell, 1990). The environment in which organizations operate is never constant and given its composition and forces therein, it presents unique challenges to organizations and their management and hence the need for crafting of appropriate and sustainable response strategies.

The response strategies that organizations adopt in order to cope with the changes in the environment have been of academic interest for many years, especially in the corporate world but little attention to public institutions, HEIs included. Indeed the importance of responding appropriately and in a timely manner to the ever turbulent and uncertain macro-environment cannot be gainsaid (Ansoff and McDonnell, 1990). Strategic response is about restructuring by adopting new strategies that match the challenges from the environment (Johnson, Scholes, and Whittington, 2008). Porter (1985) avers that for firms to retain competitive advantage, they need to examine their environment, both internal and external and respond accordingly. Thus, environmental scanning is the first step in responding to the environmental challenges. In so doing, the firm will understand how to respond to threats, technological changes, political, economic, social and cultural challenges as well as taking advantage of opportunities (Pearce and Robinson, 2011). Although several explanations of strategic action/responses have been developed, two views have been particularly dominant - industry structure and managerial cognition. The industry structure view assumes complete rationality on the part of strategic decision makers and contends that industry structure influences the timing and effectiveness of strategic actions. In contrast, the managerial cognition literature suggests that bounded rationality prevents top managers from developing a complete understanding of their environment (Nadkarni and Barr, 2008). From a university perspective, one of the response strategy that has been used in Kenya to cope with financial challenges is the introduction of the much-talked about 'parallel degree programmes', mainly introduced for the purpose of generating funds. This is a strategy of admitting full fee-paying students over and above the students who are admitted with government subsidy (Odhiambo, 2013). Mathooko (2013) established various managerial and environmental challenges faced by public universities in Kenya. The present study is an extension of this and seeks to establish the response strategies that public universities in Kenya have adopted in response to the environmental changes with a view to gaining sustainable competitive advantage.

\section{Research Problem}

Organizations world over face numerous challenges in their operations particularly, business environmental and managerial challenges. Irrespective of the nature of challenge encountered, appropriate response strategies have to be put in place to counter them and enable the organization achieve sustainable competitive advantage. It is argued that after environmental analysis, an organization will choose a strategy in response to the opportunities and threats it is facing. However, the response strategies applied have to be chosen carefully because not all response strategies lead to improved performance. In Kenya, universities have experienced various changes in their external environment, prompting responses from players in the higher education sub-sector with the objective of mitigating risks and taking advantage of opportunities. This has triggered research in the area of strategic management through application of clear and sustainable response strategies. Past research has been carried out on problems facing the public universities, especially focusing on funding, resources (human and physical), staff remuneration, political interference and research in view of changing environments and government policies. With dwindling financial support from the government, various managerial and environmental challenges have been identified (Mathooko, 2013). This is coupled with competition from the increasing number of private universities which have better facilities, infrastructure and terms of service, hence, competing for students and human resource.

In the past, studies on strategic response to environmental changes/challenges have been conducted mainly in for-profit organizations. In HEIs, Ofori and Atiogbe (2012) looked at the challenges facing strategic planning in universities in Ghana while Mutula (2002) and, Ndirangu and Odoto (2011) investigated the problems facing university education and the challenges in teaching and learning in Kenya's public universities, respectively. Ekundayo and Ajayi (2009) also looked at the challenges facing university management in Nigeria. Mukhoko (2010) investigated the influence of strategic planning at the University of Nairobi. While these studies compare well with the current study, majority were case studies thereby limiting generalization and further they focused on general problems without addressing the response strategies put in place to counter the challenges. This study, therefore, sought to establish the coping strategies adopted by public universities in Kenya to address the challenges posed by the ever changing environment. 


\section{Literature Review}

\subsection{Concept of Strategy}

Strategy is a multifaceted concept that has been defined in several ways. According to Thompson Jr., Strickland and Gamble (2008), strategy is a game plan for achieving good business performance. This means that strategy is some kind of a plan to help a business excel above competitors. The same view is echoed by Clegg, Carter, Kornberger and Schweister (2011) when they argue that strategy addresses major initiatives, either intended or emergent, which involve managers using resources to enhance performance in competitive environments. Johnson et al. (2008), on the other hand, observe that 'strategy is the direction and scope of an organization over the long term....'. This means that strategy has to do with the vision the organization has for the future. Strategy gives a general direction for the organization and its various components to achieve a desired state in the future. Strategy, therefore, results in utilizing and allocating the scarce resources within the organizational environment so as to meet the present objectives (Pearce and Robinson, 2011). Ronda-Pupo and Guerras-Martin (2012) have extended recent reflection on the evolution of strategic management by analyzing the field's object of study: strategy. Despite its wide diffusion and the application of central models and concepts, there are many definitions of the strategy concept and strategic management, most of which lack an integrating nature (Nag, Hambrick and Chen, 2007). Further, although strategy is one of the most taught and studied concept, it is paradoxically also one of the least understood (Ronda-Pupo and Guerras-Martin, 2012). In order, therefore, to understand the nature of strategic management and response strategies, it is important to understand what strategy is, since the strategic management process means defining and managing the organization's strategy. Although different scholars have emphasized different aspects of strategy, holistically, strategy can, for example, be said to be concerned with plans for winning, the means by which a business competes and the direction taken by a business for success. Therefore, organizations use strategy for different purposes at different times or they use strategy for more than one purpose at the same time. Although strategy had in the past been a reserve of the for-profit organizations, today many not-for-profit organizations, including public institutions are including strategy in their organizational planning.

Organizational strategies are classified into three different levels, corporate, business and functional levels with each level having distinct characteristics. For example, the corporate level strategy is concerned with domain selection or which industry sector(s) to compete in, whereas the business level strategy is concerned with the domain navigation which includes how to compete in a selected market segment. Functional-level strategies are derived from the business-level strategy and focus on the maximization of resource productivity (O'Regan, Kling, Ghobadian and Perren, 2012). In management, the concept of strategy is taken in broader terms. According to Jauch and Glueck (2010), strategy is the unified, comprehensive and integrated plan that relates the strategic advantage of the firm to the challenges of the environment and is designed to ensure that basic objectives of the enterprise are achieved through proper implementation process. In general, corporate-level strategy is too aggregated to enable satisfactory understanding of strategic responses to environmental influence, while functional-level strategies rarely indicate a strategic response on their own (O'Regan et al., 2012). Most of the theory development on strategy framework assumed that it occurs in the for-profit sector. This leaves the non-profit organizations (like universities) to either interpret the empirical findings regarding strategy framework to fit the non-profit sector or reject the findings as inapplicable (Phipps and Burbach, 2010). Available evidence suggests that strategic approaches in non-profit organizations may be different (Thach and Thompson, 2007). The higher education world over has grown into an industry and the three levels of strategy are currently applicable. Strategy is in fact a management game plan to outwit competitors through offering goods and services beyond the customers' expectations and also through creating and innovating new goods and services as per new demands and reposition the firm more competitively in the market. Strategy can, therefore, be seen as matching of resources and activities of an organization to the environment in which it operates and the strategic fit (Porter, 1980). With the speed at which global education is changing coupled with ever changing customer demands, strategic management becomes a rule rather than an exception.

Contingency theory posits that the environment, managers and organizational factors all play a role in determining strategic direction. Contingency theory presumes that the ability of managers to influence organizational outcome is restricted by environmental factors (Finkelstein and Boyd, 1998) and organizational factors (Carpenter and Golden, 1997). Several researchers have in the past tried to integrate managerial processes into a theory of resource management, for example, structuring, bundling and leveraging, although scholars working in the resource-based tradition have not fully explored the actions or responses firms take to create and sustain an advantage or when those responses matter most (Holcomb, Holmes Jr. and Connelly, 2009). In other words, response or decision speed may enable firms in dynamic and non-dynamic environments to exploit opportunities before they disappear (Stevenson 
and Gumpert, 1985) and also thwart threats before it is too late, and the higher education institutions are no exception. It has been argued that effective public administration in the age of result-oriented management requires public agencies to develop a capacity for strategic management, the central management process that integrates all major activities and functions and directs them towards advancing an organization's strategic agenda (Poister and Streib, 1999). Further advances have been made to indicate that university strategies can be limited to a reactive response to environmental pressures, to a simple mechanism for resource allocation according to predefined rules in order to maintain a vulnerable internal balance or by a low degree of autonomy in managing resources (Fumasoli and Lepori, 2011). Considering universities as formal organizations leads to a conception of strategies being as change instruments in the hands of management (Krücken and Meier, 2006). In the demanding environment facing HEIs, one of the key challenges facing educational planners and management teams relate to the ability to identify long-term strategic vision that can be delivered effectively - through best practices strategic management techniques that allow the institution to balance the pressures of change, continuity and resources (Richards, O'Shea and Connolly, 2004). Unfortunately, many organizations are failing to meet such challenges because they continue to base strategic planning on traditional strategic planning processes - those designed to optimize strategic decision-making in relatively predictable environments as opposed to today's uncertain and unpredictable environment (Richards et al., 2004).

\subsection{Response Strategies}

Response strategies are those choices made by managers that commit important resources, set important precedents and/or direct important firm-level actions besides shaping a firm's direction (Dean and Sharfman, 1996). In any organization, response strategies are formulated and implemented as an activity within the broad strategic management that serves as a framework within which choices are made concerning the nature and direction of the organization (Stoney, 2001). This framework helps in the allocation of resources in order to enhance financial and strategic performance (Ofori and Atiogbe, 2012). Stoney (2000) advances that strategic management ensures that the organization has appropriate structures, processes and culture or mindset to carry through a programme of change depending upon the size of an organization, and the proclivity to change of its business environment. However, no single strategic managerial method dominates, and the concept of strategic management remains a subjective and context-dependent process (Nag, et al., 2007). With the expansion of higher education and dwindling government funding, the HEIs are left with no option but to craft coping strategies. For this reason, empirical investigation is needed to identify such coping strategies.

Executives of firms employ response strategies in order to deal effectively with everything that affects the growth and profitability of the firm so that it can position itself optimally in its competitive environment by maximizing the anticipation of environmental change (Pearce and Robinson, 2011). An organization is considered efficient and operationally effective if it is characterized by coordination between objectives and strategies. Therefore, there has to be an integration of the parts into a complete structure, that is, operate as a system. Available literature indicate that while planning a response strategy, it is essential to consider that decisions are not taken in a vacuum and that any act taken by an organization is likely to be met by a reaction from those affected, competitors, customers, employees or suppliers. As such, making response strategies more meaningful requires transitioning from strategic planning to the broader process of strategic management, which involves managing an organization's overall strategic agenda on an ongoing rather than on an episodic basis, as well as ensuring that strategies are implemented effectively (Poister, 2010). In developing countries, Kenya included, universities are still stuck with traditional strategic planning and are slowly moving towards broad strategic management with a view to attaining sustainable competitive advantage. Response strategies enables a firm to counter competition so as to ensure its future growth and profitability in the industry, hence coping with changes in the environment among other challenges. The processes that underlie effective strategic decision-making matter for organizational outcome, leading to both organizational effectiveness and efficiency (Mitchell, Shepherd, and Sharfman, 2011). These processes are influenced by manager's prior knowledge and experiences, the organizational context in which they are embedded (Kaplan, 2008) and the nature of the environment itself (Nadkarni and Barr, 2008). There are two types of response strategies, namely, strategic responses and operational responses (Ross, 2011). This is irrespective of whether the organization is for-profit or not-for-profit. Strategic responses are fundamental and directional, and over-arching while operational responses primarily affect the day-to-day implementation of strategic decisions.

\subsubsection{Strategic Responses}

Strategic responses are the decisions that are concerned with the whole environment in which the firm operates, the entire resources and the people who form the company and the interface between the two (Ross, 2011). Strategic 
responses enable organizations to cope with increased uncertainty and turbulence in the micro- and macro-environment and they include long range planning, new venture development, budgeting and business policy (Pearce and Robinson, 2011). They consider what the organization needs in the future to achieve its desired aims and establishes an approach to change considering the key players, barriers and enablers of change. They focus on the effectiveness of the entire organization and require more resources to implement. It is through strategic responses that an organization is able to position and relate itself to the environment to ensure its continued success and also secure itself from surprises brought about by the changing environment (Denis, Lamothe and Langley, 2001). Higher education institutions are currently operating in a turbulent and dynamic environment. For these institutions, therefore, to survive the need to put in place sustainable response strategies cannot be underestimated. Currently, some HEIs have adopted corporate-like strategies yet very little documented information is available.

Strategic responses that have been adopted by organizations to counter macro-environment challenges can be classified as: (1) generic strategies - These are usually referred to as Porter's generic strategies. Porter's generic strategy matrix, highlights cost leadership, differentiation and focus as the three basic choices and has been applied by firms seeking competitive advantage. Indeed, Porter's generic topology has provided strategic response platform for organizations (Porter, 1980; 1985). These strategies are applied at the business unit level and are called generic strategies because they are not firm or industry specific. (2) grand strategies - a grand strategy is defined as 'a comprehensive general plan of major actions through which a firm intends to achieve its long term objectives' and contend that this is supported by a 'coordinated and sustained strategic management effort' (Pearce, Robbins and Robinson, 1987). They are the overall drivers of strategic actions; however, it has been argued that using the concept of grand strategies requires caution as many firms may operate in more than one environment or indeed have different interpretations or perceptions of the environment (O'Regan et al., 2012). Grand strategies include mergers and acquisitions, diversification and strategic alliances among others. Other strategic responses that have been adopted by organizations to counter micro- and macro-environmental challenges include new product developments, innovations (Johnson et al., 2008) downsizing, business process re-engineering and use of information technology to speed business processes and communication (Pearce and Robinson, 2011). Although strategic responses have previously been adopted by for-profit organizations, not-for-profit organizations including HEIs are slowly adopting them although little empirical evidence is available on the extent they are adopted by HEIs in Kenya.

\subsubsection{Operational Responses}

Operational responses involve actions that are taken to improve operations in an organization. This could be through designing and controlling the processes of production and redesigning business (Ross, 2011). It involves crafting and implementing operation strategies which specify the policies and plans for using the organization resources to support its long term competitive strategy (Johnson et al., 2008). An operational strategy is the total pattern of decisions which shape the long term capabilities of any type of operations and their contribution to the overall strategy through the reconciliation of market requirements with operation resources (Pitt, 2000). It is a tool that helps to define the methods of producing goods or service offered to the customer and its role is to provide a plan for operations function so that it can make the best use of its resources. Such strategies are concerned with how parts of an organization deliver effectively the company and business strategies in terms of resources, processes and people. The responses applied depend on the managers' understanding of relevant contingencies, including contextual factors that affect competitors' resources as well as their own (Holcomb et al., 2009). Operational responses include: product or service, process, research and development, location, inventory management, quality, capacity and human resource responses (Ross, 2011). However, all firms, even in the same industry grouping, do not respond to operating environment in the same way (O'Regan et al., 2012). Indeed, with new universities having been established in the rural areas of Kenya which is a departure from the past, it remains to be established whether the universities adopt the same coping strategies.

Porter (1980) views operational responses as part of planning process that coordinates operational goals with those of the target organization. Further, Ansoff and McDonnell (1990) assert that the management system used by a firm is a determining component of the firm's responsiveness to the environmental changes because it determines the way that management perceives the environment, the impact on the firm and decides what to do through implementation. These operational responses are responsible for ensuring that business operations are efficient in terms of using as few resources as needed, and effective in terms of meeting customer requirements. In essence, operational responses are technical decisions which help execution of strategic responses. All in all, the nature of coping strategies and the extent to which they are adopted by HEIs in Kenya is yet to be explored and empirical evidence provided. 


\section{Research Methodology}

The research design adopted for this study was descriptive design and the study was a survey in form of a census. For the purpose of this study, the population constituted all public universities in Kenya. Currently there are 31 universities in Kenya, including 22 fully-fledged universities and nine university colleges. In light of this small number and the fact that the respondents were members of the university top management team, the study was conducted in form of a census.

\subsection{Data Collection Method}

The study collected both primary and secondary data. The primary data were collected by carrying out a cross-sectional survey of the entire population as well as observations and interviews. Secondary data were collected from published works, print media and, universities and government documents in public domain. Primary data were collected using a Likert-type scale by administering a structured questionnaire. The Likert-type questions/items in the questionnaire were closed so as to permit more direct comparability of the responses and eliminate question/statement variability. The questionnaire included a 5-point Likert-type scale, indicating the extent to which individual questions or statements (items) were operationalized to reflect the intended variables and enable respondents to provide quantifiable information, that is, [1] - not at all; [2] - to a little extent; [3] - to a moderate extent; [4] - to a great extent and [5] - to a very great extent. The respondents were selected using a non-probabilistic sampling technique, in particular judgmental purposive sampling, that is, the conscious selection by the researcher of certain participants to include in the study (Burns and Grove, 2005). For this reason, the respondents to whom the questionnaire was administered comprised all vice-chancellors (VCs) and deputy vice-chancellors (DVCs) of the public universities and, all the principals and deputy principals of the public university colleges. This was guided by the fact that they are the ones who carry out the various managerial functions, experience challenges posed by the changing environment and craft coping strategies. Distribution of the questionnaire was a combination of mail and 'drop-and-pick-later' methods to ensure reduction in biasing errors, greater degree of anonymity for respondents, greater accessibility to geographically dispersed respondents and to reduce distorted self-reports and social desirability.

\subsection{Reliability and Validity of the Questionnaire}

In order to ensure validity and reliability, the questionnaire was composed of carefully constructed statements/items to avoid ambiguity. The questionnaire was pre-tested to evaluate it for clarity, style, meaningfulness and ease or difficult of completion. Revision of the questionnaire was made based on the feedback to ensure consistence and quality prior to final distribution. This assured that the questionnaire was clear and well-understood by potential respondents.

\subsection{Data Analysis}

The data were subjected to descriptive statistics that is, the mean for central tendency and standard deviation for variability. The data were subjected to further statistical analysis procedures within the Statistical Package for Social Scientists (SPSS). The secondary data from secondary documents was analyzed using content and logical analyses techniques. The study also sought to determine whether significant difference existed with respect to the variables tested in relation to the age of the university and the university status (old, new and university colleges). This was accomplished by utilizing inferential statistics and analyzed using SPSS. The t-test statistic and Analysis of Variance (ANOVA) statistic for comparison were used specifically to find whether there was any significant difference between and among the variables.

\section{Results and Discussion}

\subsection{Response Strategies}

The study looked at strategic and operational responses. The number of respondents was 91 . A total of 63 completed and returned the questionnaire, giving an effective response rate of 69.4 percent.

\subsection{Strategic Responses}

The study investigated the response strategies adopted by public universities to cope with changes in the environment, among them Porter's generic competitive strategy model (cost leadership, differentiation and focus) and grand strategies as applied in business entities. The public universities in Kenya used Porter's generic competitive strategy model and grand strategies as some of the response strategies to cope with the changes in the environment 'to a great extent' overall (Table 1). Of the Porter's three generic competitive strategies, cost leadership and differentiation were adopted 'to a great extent'. In the cost leadership strategy, cost minimization in non-core 
activities and outsourcing non-core services were adopted 'to a great extent' while in differentiation, being the best university/university college in the vicinity, offering the best market-driven programmes and establishing brand equity were adopted 'to a great extent'. In focus strategy, focusing on a particular clientele was adopted 'to a great extent'. These generic strategies have been used by corporate organizations to achieve sustainable competitive advantage. It can, therefore, be argued that public universities in Kenya are moving from operating as public entities to adopting corporate models (corporatization).

Table 1. Mean and standard deviation of the extent to which respondents adopted Porter's generic competitive strategy model and grand strategies

\begin{tabular}{lccl}
\hline Strategic response & Mean* & Standard deviation & Verbal interpretation \\
\hline Cost leadership & 3.6 & 0.87 & To a great extent \\
Differentiation & 3.9 & 0.71 & To a great extent \\
Focus & 3.3 & 0.95 & To a moderate extent \\
Diversification & 3.4 & 0.94 & To a moderate extent \\
Strategic alliances & 3.7 & 0.75 & To a great extent \\
Overall & 3.6 & 0.61 & To a great extent \\
\hline
\end{tabular}

$\mathrm{n}=63$

* The analysis is based on the ranges $1-1.5$ : Not at all, $1.6-2.5$ : To a little extent, $2.6-3.5$ : To a moderate extent, $3.6-4.5$ : To a great extent and 4.6-5: To a very great extent

Universities that consider a broad market strategy, cost leadership and differentiation offer a wide range of programmes as seen in the expansion strategy where respondents used expansion as a response strategy 'to a moderate extent'. These universities offer varied modes of delivery including full time, part-time, evening time and distance learning programmes for different economic classes as observed in this study and by Ronquillo (2012). The public universities in Kenya try this by attracting students from rural areas by opening branches in smaller towns in the rural areas. In higher education, applying focus strategy, universities concentrate on a narrow student or programme segment, and within that segment they manage to develop the best offer and capture students' interests. This discourages other providers from competing directly. In this case, students have less choice and are left with fewer alternatives to choose from or have to do the course because of the nature of their job. This kind of strategy has been used by Kenyatta University and Egerton University in providing training for the disciplined forces. The goal of domain creation strategies is to add related domains, to diversify or to spread risks (Cameroon, 1983). These strategies include completely new programmes offerings in high demand areas. They create new opportunities for institutional success while minimizing cost where resources are decreasing (Cameroon, 1983).

The main domain offence and domain creation strategies employed by Kenyan public universities include franchising to commercial colleges, establishment of satellite campuses and introducing new programmes, usually in fields beyond the universities' core areas of strength, such as health sciences, law, information and communication technology, management and business studies (Wangenge-Ouma and Nafukho, 2011; Wangenge-Ouma, 2012). Strategic alliances was used 'to a great extent' by the public universities (Table 1). The establishment of campuses and learning centres throughout the country, several of which are exclusive to private students is another domain defense and domain creation strategy employed by almost all of the Kenyan public universities. The respondents indicated that this response strategy is used 'to a great extent'. Public universities are, therefore, emerging as the key providers of private education in Kenya and if the trend of exclusive pockets of private students continues, a new kind of private university seems to be emerging, namely, private universities owned by public universities (Wangenge-Ouma, 2012). In addition some universities franchise their degree offerings to middle level colleges who get name recognition but pay for it (Iraki, 2011). Given the nature and history of public universities in Kenya, the strategic responses adopted by the universities may vary.

Using t-test analysis, this study shows that there was a significant difference $(\mathrm{p}<0.05)$ in the adoption of differentiation strategy between the old and new universities (Table 2). This difference could be due to the fact that the new universities are yet to develop the common traditional programmes typical of a university and also the fact that the new universities may not have established brand identity to warrant differentiation. 
Table 2. The difference between the extent to which respondents in new and old universities adopted which Porter's generic competitive strategy model and grand strategies

\begin{tabular}{lllcccc}
\hline Strategic Response & Category & $\mathrm{n}$ & Mean* & $\begin{array}{c}\text { Standard } \\
\text { deviation }\end{array}$ & $\mathrm{t}$ & $p$ \\
\hline Cost leadership & New** & 45 & 3.3 & 0.85 & 1.500 & 0.139 \\
Differentiation & Old & 18 & 3.7 & 0.89 & & \\
& New & 45 & 3.3 & 0.72 & 2.819 & $0.044^{* * *}$ \\
Focus & Old & 18 & 4.1 & 0.64 & & \\
& New & 45 & 3.3 & 0.91 & 0.516 & 0.608 \\
Diversification & Old & 18 & 3.4 & 1.08 & & \\
Strategic alliances & New & 45 & 3.0 & 0.99 & 0.147 & 0.883 \\
& Old & 18 & 3.2 & 0.86 & & \\
Overall & New & 45 & 3.4 & 0.76 & 1.313 & 0.194 \\
& Old & 18 & 3.6 & 0.67 & & \\
& New & 45 & 3.3 & 0.58 & 1.551 & 0.126 \\
\hline
\end{tabular}

* The analysis is based on the ranges $1-1.5$ : Not at all, 1.6-2.5: To a little extent, $2.6-3.5$ : To a moderate extent, $3.6-4.5$ : To a great extent and 4.6-5: To a very great extent

** Includes new universities and university colleges

*** Significantly different at $\mathrm{p}<0.05$

Depending on the level of development and status, the three categories of public universities (old, new and university college) may differ in the choice of Porter's generic competitive strategies and grand strategies adopted. Table 3 shows that there was no significant difference $(\mathrm{p}<0.05)$ in the adoption of Porter's generic competitive strategies and grand strategies among the three categories of universities. This implies that the status of the public university does not dictate the adoption of these strategies but rather the environment in which they operate which seems to be similar in this case. Among the grand strategies, the strategic alliances and collaborations that were adopted 'to a great extent' were those with local community in provision of students and staff welfare (3.7) and with research organizations to enhance research capacity (3.8). Provision of student welfare, especially accommodation is one of the challenges facing all public universities, worst hit being those in the rural area. With dwindling funds from the government, the public universities have entered into strategic alliances with foreign universities through memoranda of understanding in order to build both physical and human capacity through collaborative programmes.

Table 3. One-way ANOVA test for the differences among respondents from the three categories of universities (university colleges, new universities and old universities) on the adoption of each dimension of Porter's generic competitive strategy model and grand strategies

\begin{tabular}{|c|c|c|c|c|c|c|}
\hline Strategic response & Source & $\begin{array}{l}\text { Sum of } \\
\text { squares }\end{array}$ & $\mathrm{df}$ & $\begin{array}{c}\text { Mean } \\
\text { squares }\end{array}$ & $F$ & $p$ \\
\hline \multirow{3}{*}{ Cost leadership } & Between groups & 1.684 & 2 & 0.842 & \multirow{3}{*}{1.106} & \multirow{3}{*}{0.338} \\
\hline & Within groups & 43.406 & 60 & 0.762 & & \\
\hline & Total & 45.090 & 62 & & & \\
\hline \multirow[t]{3}{*}{ Differentiation } & Between groups & 1.622 & 2 & 0.811 & \multirow{3}{*}{1.626} & \multirow{3}{*}{0.206} \\
\hline & Within groups & 28.439 & 60 & 0.499 & & \\
\hline & Total & 30.061 & 62 & & & \\
\hline \multirow[t]{3}{*}{ Focus } & Between groups & 0.872 & 2 & 0.436 & \multirow{3}{*}{0.473} & \multirow{3}{*}{0.625} \\
\hline & Within groups & 52.54 & 60 & 0.922 & & \\
\hline & Total & 53.412 & 62 & & & \\
\hline \multirow[t]{3}{*}{ Diversification } & Between groups & 0.05 & 2 & 0.025 & \multirow{3}{*}{0.027} & \multirow{3}{*}{0.973} \\
\hline & Within groups & 52.995 & 60 & 0.930 & & \\
\hline & Total & 53.046 & 62 & & & \\
\hline \multirow[t]{3}{*}{ Strategic alliances } & Between groups & 2.242 & 2 & 1.121 & \multirow{3}{*}{2.116} & \multirow{3}{*}{0.130} \\
\hline & Within groups & 30.197 & 60 & 0.530 & & \\
\hline & Total & 32.439 & 62 & & & \\
\hline \multirow[t]{3}{*}{ Overall } & Between groups & 0.891 & 2 & 0.445 & \multirow{3}{*}{1.192} & \multirow{3}{*}{0.311} \\
\hline & Within groups & 21.305 & 60 & 0.374 & & \\
\hline & Total & 22.196 & 62 & & & \\
\hline
\end{tabular}


Diversification, both in related business and in unrelated businesses was adopted by the public universities 'to a moderate extent'. Content analysis revealed that some of the universities were also adopting joint ventures through the public-private partnership (PPP) model, especially with respect to addressing the managerial challenge of student accommodation. Some universities, like Maseno University and Kenyatta University have already advertised for expression of interest under the PPP model. Other public universities have diversified into the tourism and hospitality industry, and although in some cases seen as facility for training, the key objective is income generation. As pointed out by Porter (1985), it is imperative that organizations (universities) have their strategies that reflect their needs and plans, given the institutional arrangements and external conditions. Some universities took the risk of programme differentiation when they started offering programmes other universities did not offer. Some succeeded and others failed. Ronquillo (2012), indicated that programmes differentiation in a university should be accompanied by a corresponding training of faculty staff, a condition that lacked among the Kenyan public universities. The current results show that strategic alliance which is an agreement between two or more organizations to cooperate in a specific business activity, so that each benefits from the strength of the other, and gain competitive advantage was a preferred mode of entry into new markets. Organizations enter into strategic alliances for four main reasons, ease of market entry, shared risks, shared knowledge, critical skills and expertise, and synergy and competitive advantage (Išoraite, 2009), facts supported by the results from this study. This study has established that most universities enter into strategic alliances with commercial colleges 'to a moderate extent' and with local communities 'to a great extent', the latter being aimed at provision of staff and student welfare.

Strategic alliances were used as one of the most popular expansion and response strategy. This could be due to the fact that there is no investment on the part of the public university and that it allows for the spread of risks. It is like a form of franchising programme on the part of the public university to the commercial institution. Kitoto (2005) in her study on competitive strategies adopted by universities in Kenya observed that both public and private universities use generic and grand strategies to survive in the competitive market. In addition, Gongera and Okoth (2012) in their study of middle level colleges in Mombasa, Kenya found that these institutions have crafted strategies that are focused on offering unique products that are generally valued by customers and thus following the differentiation strategy. University strategies can be limited to a reactive response to environmental pressures, to a simple mechanism for resource allocation according to predefined rules in order to maintain a vulnerable internal balance or by a low degree of autonomy in managing resources. Following this perspective, university nature as loosely coupled systems would lead to emergent strategies based on ad hoc responses by learning organizational units or by adaptation through simultaneous tracking (Fumasoli and Lepori, 2011). Considering universities as formal organizations leads to a conception of strategies as change instruments in the hands of management (Krücken and Meier, 2006). Therefore, the application of strategic management to the context of HIEs is feasible based on two premises: (1) an institution of higher learning is an entity with its own goals and coherent goal-directed actions and (2) an institution of higher learning is a network of participants who use their association to pursue their individual goals (Huang and Lee, 2013). The success of private HEIs in Malaysia has been shown to use Porter's generic competitive strategy model to beat competition in the higher education industry and their response to the challenges in the environment are guided by Porter's five competitive forces framework (Hua, 2011).

\subsection{Operational Strategies}

The operations strategies that have been adopted by public universities are shown in Table 4. The results indicate that the provision of leadership by management in formulating response strategies and mounting of evening and weekend classes are used 'to a great extent' by the respondents, besides value chain analysis, strategic fit, participatory management, benchmarking and running the organization as a corporate entity. Accommodation of students has been highlighted as one of the main managerial challenges faced by universities located in rural and urban centres (Mathooko, 2013). To address this challenge the response strategy adopted by most of the universities was to enter into partnership with the local communities to offer accommodation or into a PPP arrangement on a build-operate-transfer model. Indeed, inadequate housing at local universities has caused a steep rise in rents charged by private developers, a move that has raised the overall cost of education. 
Table 4. Mean and standard deviation of the of the extent to which respondents adopted various operational response strategies

\begin{tabular}{|c|c|c|c|}
\hline Response strategy & Mean & $\begin{array}{l}\text { Standard } \\
\text { deviation }\end{array}$ & Verbal interpretation \\
\hline $\begin{array}{l}\text { - Top management provides leadership and direction in } \\
\text { formulating response responses }\end{array}$ & 4.1 & 0.82 & To a great extent \\
\hline $\begin{array}{l}\text { - Strategic plans are altered along the way to fit } \\
\text { environmental changes }\end{array}$ & 3.2 & 0.85 & To a moderate extent \\
\hline $\begin{array}{l}\text { - The university ensures that there is a strategic fit } \\
\text { between strategies and the environment }\end{array}$ & 3.6 & 0.93 & To a great extent \\
\hline - Distributed leadership/decentralization & 3.4 & 0.91 & To a moderate extent \\
\hline - Value chain analysis to cut on costs & 3.5 & 1.05 & To a moderate extent \\
\hline $\begin{array}{l}\text { - Paying higher hourly rates to part-time lecturers than } \\
\text { the competition }\end{array}$ & 3.0 & 1.05 & To a moderate extent \\
\hline $\begin{array}{l}\text { - Appointment of staff on permanent and pensionable } \\
\text { terms }\end{array}$ & 3.4 & 1.14 & To a moderate extent \\
\hline $\begin{array}{l}\text { - Offering attractive and unique allowances to attract } \\
\text { competent and experienced staff }\end{array}$ & 3.3 & 1.07 & To a moderate extent \\
\hline - Institutionalizing internal part-time teaching & 3.3 & 0.97 & To a moderate extent \\
\hline - Participatory management & 3.6 & 0.98 & To a great extent \\
\hline - Enterprise resource planning to improve operations & 3.4 & 0.92 & To a moderate extent \\
\hline - Mounting programmes that need minimum investment & 3.2 & 1.13 & To a moderate extent \\
\hline - Expansion & 3.4 & 0.90 & To a moderate extent \\
\hline - Accommodation for all students & 3.0 & 1.16 & To a moderate extent \\
\hline - Training core staff & 3.3 & 1.02 & To a moderate extent \\
\hline - Benchmarking & 3.6 & 0.99 & To a great extent \\
\hline - Weekend and evening classes & 4.3 & 1.27 & To a moderate extent \\
\hline - Restructuring/Re-engineering & 3.2 & 0.99 & To a moderate extent \\
\hline $\begin{array}{l}\text { - Establishment of a fully-fledged marketing } \\
\text { department }\end{array}$ & 3.0 & 1.25 & To a moderate extent \\
\hline - Implementation of ISO 9001:2008 QMS & 3.6 & 1.27 & To a great extent \\
\hline - Running the university like a corporate organization & 3.6 & 0.91 & To a great extent \\
\hline - Hiring out university resources & 2.9 & 1.12 & To a moderate extent \\
\hline Overall & 3.3 & 0.51 & To a moderate extent \\
\hline
\end{tabular}
$\mathrm{n}=63$

* The analysis is based on the ranges $1-1.5$ : Not at all, $1.6-2.5$ : To a little extent, $2.6-3.5$ : To a moderate extent, $3.6-4.5$ : To a great extent and 4.6-5: To a very great extent

In Kenya, a university degree is moving from being desirable, in many cases, to being a necessity. The universities have capitalized on this change in the economy and have coined the terms 'mature student' or 'evening students' which is basically 'life-long learning' as a marketing tool to ensure repeat business for their product offerings. Mounting of evening classes for mature and working people was a strategy adopted by public universities 'to a great extent' to increase student numbers and also generate more funds. A similar observation has been reported previously by Svensson and Wood (2010). Kenyan universities have embraced the marketing concept and this is evidenced by the establishment of fully-fledged marketing departments as a response strategy by the respondents 'to a moderate extent' that are focused on capitalizing on the newfound opportunities (Svensson and Wood, 2010). Due to the evening and weekend programmes, most public universities in Kenya have a population of self-sponsored students higher than that of regular or government-subsidized students (Wangenge-Ouma, 2012), thereby creating private public universities. The programmes attended by these 'private' public students are popularly referred to as 'parallel programmes' and they are the de facto private wings of public universities as has happened in public hospitals. In large part, public universities introduced 'parallel programmes' alongside 'regular' programmes attended by government-subsidized students to augment anorexic allocations from the government (Wangenge-Ouma, 2012). 
Besides administration of a questionnaire, the study also collected secondary data and undertook content analysis. The study has unearthed some unethical response strategies used by some universities which may be detrimental to quality of service delivery and/or graduates. Information from print media and brochures indicate that some universities and the constituent colleges affiliated to them drop some cluster (mandatory) subjects for some courses in order to attract students. A case that was observed in this study is the Bachelor of Information Technology, Bachelor of Science in Information Technology and Bachelor of Business Information Technology, for both public and private universities. While one of the cluster subjects for government-sponsored students admitted through the Joint Admissions Board (JAB) is physics, information in the intake announcements in the print media and brochures for self-sponsored students do not indicate physics as one of the cluster subject. This implies that since physics is not taken by many students, dropping physics as a cluster subject, such universities have an unfair advantage in raising student numbers for these programmes as opposed to those universities which include physics as a cluster subject in their intake announcements. Since the brochures are used in exhibitions and career days/forums, students aspiring to join such universities through government sponsorship do not get the right information. Other universities admit students with a Kenya Certificate of Secondary Education (KCSE) mean grade lower than required C+ (plus) directly into degree programmes and for university certificate and diploma courses with a mean grade of D+ (plus) and C(minus), respectively at KCSE. While these certificates are terminal, a fact that is not communicated to the students, such graduates are eventually admitted to higher level academic programmes, their qualifications at KCSE notwithstanding. Since the entry requirement for the programmes is a C- (minus) and C (plain), respectively, this further poses an unfair competition for students with those universities that maintain the recommended entry requirements. This is supported by the observation that the respondents indicated that this lowering of admission criteria by some universities affected the choice of response strategy 'to a great extent' (Table 4). Further, combining of classes from different levels of study has also been observed as an unethical response strategy for alleviating the shortage of qualified staff and saving costs. Lowering of job specifications, especially for teaching staff in order to compete for the scarce and limited human resource influenced the choice of response strategies 'to a great extent' (Table 4). In other universities, students undertaking master's degrees especially in business, humanities and social sciences are allowed to start research project work (Part II) even before completing course work. This flexibility and laxity albeit unethical tends to attract many potential students, a situation that poses unfair competition.

In other cases, there is credit transfer from diploma to undergraduate degree programmes with such students entering university in either first or second semester of second year. Ideally, only related degree units can be transferred from one programme to another, that is, degree to degree. This is an unethical strategy and gives these universities an unfair competitive advantage over the others with respect to attracting and raising student numbers. The low admission criteria was also observed in most private universities where in some cases universities only indicate the minimum qualification $(\mathrm{C}+)$ without indicating the required cluster subjects and minimum subject grade required. This not only compromises quality of graduates but are unfair response strategies to beat competition for students. The low admission criteria and undeserved credit transfer used by some private universities as compared to the public universities could contribute to the exponential increase in the number of students in some private universities. The credit transfers from diploma programmes or professional certificates enables the students to finish the programme in two calendar years, assuming trimester and sometimes ahead of the students who qualified and were admitted into the university directly. In some private universities candidates with CPA (K) are even admitted into the MBA programme irrespective of whether they are graduates or not, while in other universities they start in the second or third year, their qualification at KCSE notwithstanding. This trend has influenced other universities in their response strategies and is unfair as far as competition is concerned - the playground is not level. Another highly abused strategy was the so called 'pre-university programmes' and 'bridging courses' that admit students who do not meet the minimum university requirements with as low as $\mathrm{C}$ - (minus) who transit to universities. In other universities candidates with mean grades lower than $\mathrm{C}+$ (plus) are required to sit for entrance examinations and if they pass (which is usually the case) they are admitted into degree programmes. This may be mainly due to lack of national standards in what constitutes a pre-university programme and what should be bridged. In most of the universities except University of Nairobi, where to bridge one must have a mean grade of C+ (plus) and at least a C- (minus) in the subject to be bridged, most other universities are silent on this and students who had scored as low as E (fail) are allowed to bridge. In these cases the pass rate is deliberately high to guarantee a steady transition into the undergraduate programmes and raise student numbers. Another unethical operational response strategy was found in the 'institution-based programmes' where universities both private and public reduce the number of sessions that constitute a semester to attract students who wish to finish in the shortest possible time content notwithstanding. Fees payable for some programmes was also questionable, raising the question whether the students are taught for the prescribed number of hours within the cost leadership context. 
Organizations are environmentally dependent, hence they need to employ strategic responses in order to adapt to the changing environment. The response strategies that a firm chooses are not easy decisions and some of them may turn out to be wrong but this should not be a hindrance for not coming up with creative decisions (Thompson et al., 2008). Response strategies, therefore, involve changes in the firm's strategic behavior and ensure success in transforming the future environment. Structure is important in crafting response strategies. The public university structures in Kenya have remained the same and have not evolved in response to changing internal and external environments. While operations and strategies in most public universities in Kenya have adjusted to changes in internal and external environments organizational structures have remained the same despite changes in the environment hence need for re-engineering albeit contextual.

\section{Conclusion and Implication}

Faced with many environmental and managerial challenges including intense industry competition, government control and regulation, commoditizing of education, rising costs, highly dynamic environment, and more demanding customers (students, parents and industry), the survival of public universities in Kenya has been shown to depend greatly upon the development of sustainable response strategies to remain viable and competitive, if not to achieve market leadership. This study took a novel approach to studying university system in a manner more typically reserved for business and private sector. In this context, the response strategies adopted by the public universities in Kenya are more or less similar to those applied by corporate organizations among them, grand strategies and Porter's generic competitive strategies. This indicates that the present public universities in Kenya are run like corporate entities and that the strategic management practiced in public universities in Kenya is similar to that of corporations, that is, there is 'corporatization' of public universities in Kenya. The study makes positive contribution to the strategic management literature by focusing on the relationship between environmental changes and response strategies and, hence the environment-dependence theory of not-for-profit organizations, that is, public universities.

\subsection{Contribution to Policy and Practice}

The bending of admission requirements for some disciplines and different academic levels is an unethical response strategy to attract self-sponsored students. The Kenya Universities and Colleges Central Placement Service created by the Universities Act (2012) may solve this problem by providing national guidelines for all potential candidates. The Commission for University Education (CUE) working with this body needs to streamline admission criteria to ensure uniform and fair playing ground for all universities and enhance quality of graduates. CUE should also ensure that same admission criteria are enforced for all degree programmes irrespective of whether one is admitted by public or private university and through the regular/government or self-sponsored programme. This would include setting clear guidelines on entry requirements, course duration and mode of credit transfer. It is hoped that the issue of credit transfer will be addressed through the CUE credit accumulation and transfer system (CATS) initiative. CATS is expected to facilitate credit accumulation and transfer between institutions through developing minimum standards for academic programmes and movement of students within the country and, therefore, solve the problem of unethical strategies on credit transfer observed in this study. The government needs to set national standards for pre-university programmes, institution-based programmes and bridging courses which this study has shown are misused in an attempt to beat competition. There is need to establish cost (unit cost) for various programmes since cost leadership strategy could be adopted at the expense of quality. To compete with the best in the region public universities in Kenya should mutually cooperate and establish strategic alliances among themselves, complementing each other in areas where they have advantages instead of always trying to out-do each other and looking for foreign universities partnership. There is, however, need to establish guidelines for strategic alliances to safeguard quality. Given that some universities are endowed with specific resources, it would be prudent if local public universities enter into collaborations with a view to sharing the limited resources. Such collaboration has been initiated by JKUAT and Multimedia University of Kenya in conducting training in their engineering programmes. Even dual tenure may be considered for the limited human resource, particularly teaching staff in those disciplines where there are no adequate teaching staff. Given that some universities lower job specifications in order to attract teaching staff, CUE needs to formulate guidelines on job specification for the various cadres within the teaching staff grades. In so doing, all universities will be competing for teaching staff on a level playing ground and avoid using unethical strategies to respond to changes in the external environment, further enhancing the quality of teaching in all universities. Further, the public universities should disband the rigid traditional governance models that stifle reforms to more pro-customer models that enable the institutions treat students, parents and industry as customers and adopt corporate management style of the universities because they have actually become so. The information provided here could be useful in developing strategic frameworks and management guidelines for further development of higher education industry in Kenya. 


\subsection{Limitation and Opportunities for Further Research}

The study was conducted for public universities only and not all the HEIs hence generalization in all HIEs is limited. The study relied on data collected using self-reporting postal and drop-and-pick-later questionnaire, secondary data and content analysis. Ideally, it should be augmented with real-time longitudinal studies to obtain better understanding of causal relationships (both degree and direction). In addition, the study was a cross-sectional survey and the environment being dynamic, the application of the results over a long time is limited. There is need to investigate and provide empirical evidence on how the environment influences the kind of leaders in public universities especially in relation to its volatility; the most current pressing challenge may be the least challenging in the future. We, therefore, recommend that a longitudinal study or periodical study be undertaken to examine the changes in the relative effects of the various challenges within and outside HEIs. Longitudinal studies will shed light on how the response strategies evolve in the context of environmental and other influences. Public and private universities operate in the same environment. However, the results from this study cannot be generalized for all universities in Kenya since public and private universities have different structures. This calls for undertaking of a cross-sector study to ascertain whether private universities adopt same coping strategies as public universities. The findings of such research could potentially provide important insights into the differences and similarities between strategic management in the different types of HEIs.

\section{References}

Ansoff, H.I., \& McDonnell, E.J. (1990). Implanting strategic management. New York: Prentice-Hall.

Burns, N., \& Grove, S.K. (2005). The practice of nursing research: conduct, critique and utilization (5 $5^{\text {th }}$ ed.). New York: Elsevier/Saunders.

Cameroon, K. (1983). Strategic responses to conditions of decline: higher education and the private sector. Journal of Higher Education, 54, 359-380.

Carpenter, M.A., \& Golden, B. (1997). Perceived managerial discretion: a survey of cause and effect. Strategic Management Journal, 18, 187-206.

Clegg, S., Carter, C., Kornberger, S., \& Schweitzer, J. (2011). Strategy: theory and practice. London: SAGE Publications Ltd.

Dean, J.W. Jr., \& Sharfman, M.P. (1996). Does decision process matter? A study of strategic decision-making effectiveness. The Academy of Management Journal, 39, 368-396.

Denis, J., Lamothe, L., \& Langley, A. (2001). The dynamic collective leadership and strategic change in pluralistic organizations. The Academy of Management Journal, 44, 261-279.

Ekundayo, H.T., \& Ajayi, A.I. (2009). Towards effective management of university education in Nigeria. International NGO Journal, 4, 432-347.

Finkelstein, S., \& Boyd, B.K. (1998). How much does a CEO matter? The role of managerial discretion in setting of CEO compensation. The Academy of Management Journal, 41, 179-199.

Fumasoli, T., \& Lepori, B. (2011). Patterns of strategies in Swiss higher education institutions. Higher Education, 61, 157-178. http://dx.doi.org/10.100734-010-9330-x.

Gongera, E., \& Okoth, O.N. (2012). Critical analysis of competitive strategies on performance and market positioning: a case study of middle level colleges in Mombasa County. European Journal of Business and Management, 4, 71-76.

Holcomb, T.R., Holmes Jr., R.M., \& Connelly, B.L. (2009). Making the most of what you have: managerial ability as a source of resource value creation. Strategic Management Journal, 30, 457-485. http://dx.doi.org/10.1002/smj.747.

Hua, L.T. (2011). Sustainable competitive advantage for market leadership amongst the private higher education institutes in Malaysia. Journal of Global Management, 2, 227-251.

Huang, H., \& Lee, C. (2013). Strategic management for competitive advantage: a case study of higher technical and vocational education in Taiwan. Journal of Higher Education Policy and Management, 34, 611-628. http://dx.doi.org/10.1080/1360080x.2012.727635.

Iraki, X.N. (2011, November 29). The dilemma of marketing higher education in the country. Standard Newspaper, pp. 10. 
Išoraite, M. (2009). Importance of strategic alliances in company's activity. Intellectual Economics, 1, 39-46.

Jauch, L.R., \& Glueck, W.F. (2010). Strategic management and business policy. New York: McGraw-Hill Companies. Johnson, G., Scholes, K., \& Whittington, R. (2008). Exploring corporate strategy ( ${ }^{\text {th }}$ ed.). Singapore: Prentice-Hall.

Kaplan, S. (2008). Cognition, capabilities and incentives: assessing firm response to the fiber-optic revolution. The Academy of Management Journal, 51, 672-695.

Kitoto, L.A. (2005). Competitive strategies adopted by universities in Kenya. Unpublished MBA Research Project Report, University of Nairobi, Kenya.

Krücken, G., \& Meier, F. (2006). Turning the university into an organizational actor. In G.S. Drori, J.W. Meyer, \& H. Hwang (Eds.), Globalization and organization. World society and organizational change. Oxford: Oxford University Press.

Mathooko, F.M. (2013). Response strategies adopted by public universities in Kenya to environmental and managerial challenges. Unpublished MBA Research Project Report, University of Nairobi, Kenya.

Mitchell, J.R., Shepherd, D.A., \& Sharfman, M.P. (2011). Erratic strategic decisions: when and why managers are inconsistent in strategic decision making. Strategic Management Journal, 32, 683-704. http://dx.doi.org/10.1002/smj.905.

Mukokho, A.A. (2010). The influence of strategic planning on performance of public universities in Kenya: the case of the University of Nairobi. Unpublished MBA Research Project Report, University of Nairobi, Kenya.

Mutula, S.M. (2002). University education in Kenya: current developments and future outlook. International Journal of Educational Management, 16, 109-119.

Nadkarni, S., \& Barr, P.S. (2008). Environmental context, managerial cognition, and strategic action: an integrated view. Strategic Management Journal, 29, 1395-1427. http://dx.doi.org/10.1002/smj.717.

Nag, R., Hambrick, D. C., \& Chen, M.-J. (2007). What is strategic management, really? Inductive derivation of a consensus definition of the field. Strategic Management Journal, 28, 935-955. http://dx.doi.org/10.1002/smj.615.

Ndirangu, M., \& Udoto, M.O. (2011). Quality of learning facilities and learning environment: challenges for teaching and learning in Kenya's public universities. Quality Assurance in Education, 19, 208-223. http://dx.doi.org/10.1108/09684881111158036.

O'Regan, N., Kling, G., Ghobadian, A., \& Perren, L. (2012). Strategic positioning and grand strategies for high-technology SMEs. Strategic Change, 21, 199-215. http://dx.doi.org/10.1002/jsc.1904.

Odhiambo, G.O. (2013). Higher education quality in Kenya: a critical reflection on key challenges. Quality in Higher Education, 17, 299-315. http://dx.doi.org/10.1080/13538322.2011.614472.

Ofori, D., \& Atiogbe, E. (2012). Strategic planning in public universities: a developing country perspective. Journal of Management and Strategy, 3, 67-82. http://dx.doi.org/10.5430/jms.v3n1p67.

Pearce, J.A., \& Robinson, R.B. (2011). Strategic management: formulation, implementation and control (12 ${ }^{\text {th }}$ ed.). Singapore: McGraw-Hill.

Pearce, J.A., Robbins, D.K., \& Robinson, R.B. (1987). The impact of grand strategy and planning formality on financial performance. Strategic Management Journal, 8, 125-134.

Phipps, K.A., \& Burbach, M.E. (2010). Strategic leadership in non-profit sector: opportunities for research. Journal of Behavioral and Applied Management, 11, 137-154.

Pitt, C. (2000). Implementation issues in core competence strategy making. Strategy Change, 9, 115-127.

Poister, T. H., \& Streib, G.D. (1999). Strategic management in public sector: concept, models and processes. Public Productivity and Management Review, 22, 308 - 325. http://dx.doi.org/10.1111/j.1540-6210.201002284.x.

Poister, T.H. (2010). The future of strategic planning in the public sector: linking strategic management and performance. Public Administration Review, 70, s246-s254.

Porter, M.E. (1980). Competitive strategy: techniques for analyzing industries and competitors. New York: The Free Press. 
Porter, M.E. (1985). Competitive advantage: creating and sustaining superior performance. New York: The Free Press.

Richards, L., O'Shea, J., \& Connolly, M. (2004). Managing the concept of strategic change within higher education institutions: the role of strategic and scenario planning techniques. Strategic Change, 13, 345-359. http://dx.doi.org/10.1002/jsc.690.

Ronda-Pupo, G.A., \& Guerras-Martin, L.A. (2012). Dynamics of the evolution of the strategy concept 1962-2008: a co-word analysis. Strategic Management Journal, 33, 162-188. http://dx.doi.org/10.1002/smj.948.

Ronquillo, T.A. (2012). Analysis of competitiveness of Batangas State University College of Engineering using Porter's five competitive forces model. In: Proceedings of the 2012 AAEE Conference, Melbourne, Australia.

Ross, R.G. (2011). Operational business decisions - whose decisions are they anyway? Business Rules Journal, 12, 283-305.

Stevenson, H., \& Gumpert, D. (1985). The heart of entrepreneurship. Harvard Business Review, 63, 85-94. http://dx.doi.org/10.1108/09513540710716795.

Stoney, C. (2001). Strategic management or strategic topology? A case study into change within a local U.K. local authority. The International Journal of Public Sector Management, 14, 27-42. http://dx.doi.org/10.1108/09513550110387057.

Svensson, G., \& Wood, G. (2010). Are university students really customers? When illusion may lead to delusion for all! International Journal of Educational Management, 21, 17-28.

Thach, E., \& Thompson, K.J. (2007). Trading places: examining leadership competencies between for-profit vs. public and non-profit leaders. Leadership and Organization Development Journal, 28, 356-375. http://dx.doi.org/10.1108/01437730710752229.

Thompson Jr., A.A., Strickland III A.J., \& Gamble, J.E. (2008). Crafting and executing strategy: the quest for competitive advantage: concepts and cases ( $16^{\text {th }}$ ed.). Boston: McGraw-Hill-Irwin.

Wangenge-Ouma, G. (2012). Public by day, private by night: examining the private lives of Kenya's public universities. European Journal of Education, 47, 213-227.

Wangenge-Ouma, G., \& Nafukho, F.M. (2011). Responses to conditions of decline: the case of Kenya public universities. Africa Education Review, 8, 169-188.

Xu, X.M., Lehaney, B., Clarke, S., \& Duan, Y. (2003). Some UK and USA comparisons of executive information systems in practice and theory. Journal of End User Computing, 15, 1-19. 